\title{
Superficial siderosis and dural ectasia
}

\section{A case report}

\section{Figure $1 \quad$ T2-weighted MRI}
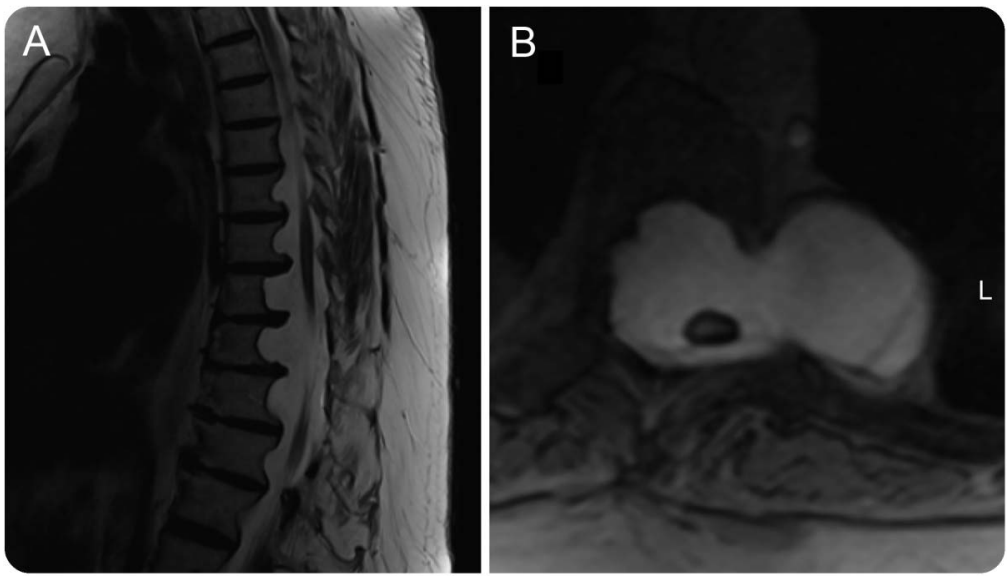

(A) Sagittal T2-weighted MRI of the spine demonstrates significant dural ectasia with scalloping of the posterior vertebral bodies from T5 to T11. (B) Axial T2-weighted MRI of the spine at the level of T9 shows left lateral meningocele formation, with a T2-hypointense rim around the spinal cord consistent with hemosiderin deposition.

A 61-year-old woman with known neurofibromatosis type 1 (NF1) presented with lower back pain, urinary retention, impaired hearing, and tinnitus. Her lower limb deep tendon reflexes were brisk bilaterally with extensor plantar responses. MRI showed extensive dural ectasia, as well as hemosiderin deposition characteristic of superficial siderosis (figures 1 and 2). CSF analysis showed elevated erythrocyte counts, protein, and ferritin. Dural ectasia and meningocele formation are recognized complications of NF1. ${ }^{1}$ In this case, friable vessels at the site of the ectatic dura are the likely source of chronic bleeding into the $\mathrm{CSF},{ }^{2}$ resulting in diffuse superficial siderosis.

Figure 2 Axial MRI

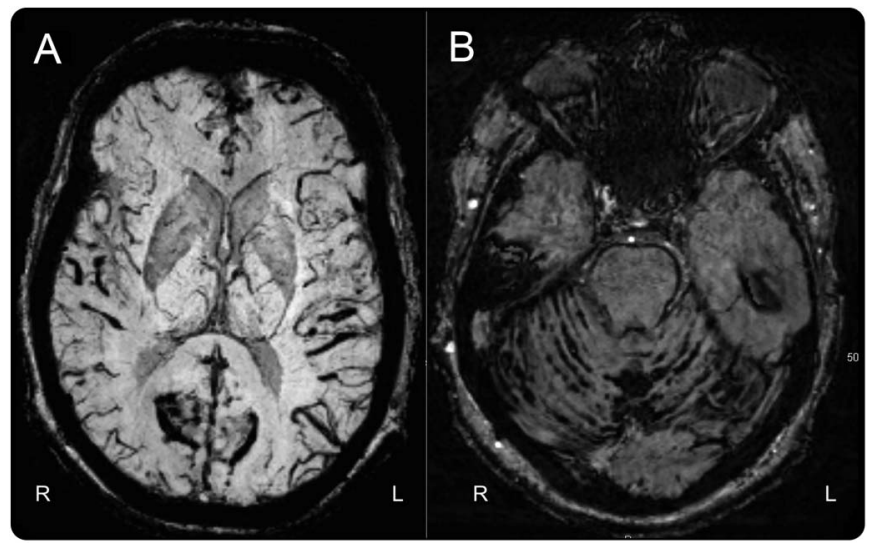

(A) Axial MRI of the brain with loss of signal on susceptibility-weighted imaging (SWI) sequences consistent with leptomeningeal hemosiderin deposition around the bilateral cerebral hemispheres. (B) Axial MRI of the brain with SWI sequences demonstrates superficial hemosiderin deposition involving the pons and the cerebellar folia. 
Meabh O'Hare, $M B, B C h, B A O$, Conor Fearon, $M B, B C h, B A O$, Eoin C. Kavanagh, MB, BCh, BAO, Brian Murray, $M B, B C h, B A O$, Timothy Lynch, $M B, B C h, B A O$

From Stanford University Hospital (M.O.), CA; Beaumont Hospital (C.F.); and Mater Misericordiae University Hospital (E.C.K., B.M., T.L.), Dublin, Ireland.

Author contributions: Meabh O'Hare collected and interpreted the clinical data and wrote the manuscript. Conor Fearon was responsible for the study concept and design and revised the manuscript for intellectual content. Eoin Kavanagh assisted in selection of images and revised image legends for intellectual content. Brian Murray revised earlier manuscript drafts for intellectual content.

Timothy Lynch revised earlier manuscript drafts for intellectual content.

Study funding: No targeted funding reported.

Disclosure: The authors report no disclosures relevant to the manuscript. Go to Neurology.org for full disclosures.

Correspondence to M. O'Hare: meabhohare@gmail.com

1. Woon CY. Dural ectasia: a manifestation of type 1 neurofibromatosis. CMAJ 2010;182:1448.

2. Kumar N, Cohen-Gadol AA, Wright RA, Miller GM, Piepgras DG, Ahlskog JE. Superficial siderosis. Neurology 2006;66: $1144-1152$.

\section{Save These Dates for AAN CME Opportunities!}

Mark these dates on your calendar for exciting continuing education conferences by the American Academy of Neurology. Learn more at AAN.com/conferences.

\section{Breakthroughs in Neurology}

- January 13-16, 2017, Phoenix, AZ, at the Sheraton Grand at Wild Horse Pass

AAN Annual Meeting

- April 22-28, 2017, Boston, MA, at the Boston Convention Center

\section{How Do YOU Compare? Access New Neurology Compensation and Productivity Report}

The AAN's 2016 Neurology Compensation and Productivity Report and customizable dashboard is now available. Whether you are a physician or practice administrator in a large or small practice setting, the 2016 Neurology Compensation and Productivity Report empowers you to:

- Compare and customize your individual practice-related data with your colleagues at local and national levels

- Determine if you are being compensated fairly relative to your peers

- Use the data in demonstrating your value to payers and to delivering quality patient care

- Discover fair market value based on your subspecialty, region, and practice type

- Create charts and graphs and download them right to your desktop

- Assess patient and practice management principals and implement efficiencies that ultimately can help improve the quality of patient care

Learn more at $A A N$.com/view/2016NeuroReport. 


\title{
Neurology
}

\author{
Superficial siderosis and dural ectasia: A case report \\ Meabh O'Hare, Conor Fearon, Eoin C. Kavanagh, et al. \\ Neurology 2016;87;1743-1744 \\ DOI 10.1212/WNL.0000000000003233
}

This information is current as of October 17, 2016

$\begin{array}{ll}\begin{array}{l}\text { Updated Information \& } \\ \text { Services }\end{array} & \begin{array}{l}\text { including high resolution figures, can be found at: } \\ \text { http://n.neurology.org/content/87/16/1743.full }\end{array} \\ \text { References } & \text { This article cites } 2 \text { articles, } 2 \text { of which you can access for free at: } \\ & \text { http://n.neurology.org/content/87/16/1743.full\#ref-list-1 } \\ \text { Subspecialty Collections } & \text { This article, along with others on similar topics, appears in the } \\ & \text { following collection(s): } \\ & \text { All Spinal Cord } \\ & \text { http://n.neurology.org/cgi/collection/all_spinal_cord } \\ & \text { MRI } \\ & \text { http://n.neurology.org/cgi/collection/mri } \\ & \text { Neurofibromatosis } \\ \text { http://n.neurology.org/cgi/collection/neurofibromatosis } & \\ & \text { Information about reproducing this article in parts (figures,tables) or in } \\ & \text { its entirety can be found online at: } \\ \text { http://www.neurology.org/about/about_the_journal\#permissions } & \text { Information about ordering reprints can be found online: } \\ \text { Permissions \& Licensing } & \text { http://n.neurology.org/subscribers/advertise }\end{array}$

Neurology ${ }^{\circledR}$ is the official journal of the American Academy of Neurology. Published continuously since 1951, it is now a weekly with 48 issues per year. Copyright (O 2016 American Academy of Neurology. All rights reserved. Print ISSN: 0028-3878. Online ISSN: 1526-632X.

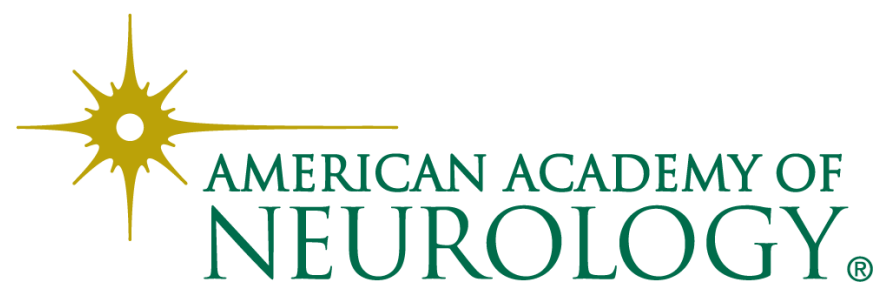

